\title{
A LOST SELAH, AND PSALM LXXXV 9 [8].
}

Dr W. Emery Barnes suggests that where SElah occurs, there usually Massorah or Midrash has been at work. ${ }^{1}$ SELAH may be taken as the earliest and simplest form of note which was attached to the Hebrew text. ${ }^{2}$ It is quite of general significance, a Nota Bene, simply calling attention to the context in which it is embedded. ${ }^{3}$ It is found in not less than five classes of passages. 'A good instance. of a verse which challenges by its contents Midrashic treatment is [Psalm] ii 2 'The rulers take counsel together'... Midrash must ask why is another so closely associated with the Holy one? The answer can be supplied from a Midrashic comment on a different passage. It is because every one who riseth up against Israel is as if he rose up against the Holy one, \&c. (Mechilta, ed. Friedmann on Exod. xv 7). Another similar passage is iv 5, 6[4,5] 'Commune ... and be silent, SELAH, offer the sacrifices of righteousness'. Here the Midrash runs 'What is meant by Be silent Selah? R. Judah said: Provided thou cease from transgression which thou hast in hand. And if thou behavest thus-what is written next, offer the sacrifices of righteousness. This means, \&c.' (Midrash Tehillim, ed. S. Buber, p. 46).*

A most difficult verse in Ps. lxxxv 9 [8] could be easily explained if Dr Barnes's theory is accepted. The difficult part of the verse in question for which no satisfactory explanation or emendation has yet been found is its last three words

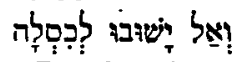

A.V. and R.V. render it 'But let them not turn again to folly'. Dr Kirkpatrick 'unto self-confidence'. But, as Dr Briggs ${ }^{5}$ rightly points out, these words make'a sentence which is not only difficult Hebrew syntax, but also interrupts the easy flow of thought characteristic

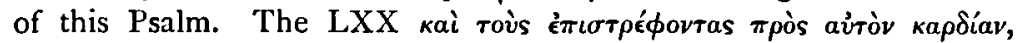
and V. et in eos qui convertuntur ad cor suggest to him the emendation

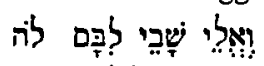

This reading, however, not only $(a)$ re-groups the letters and changes a $\supset$ into a 2 , but $(b)$ also assumes that in the present Hebrew text the scribe has changed a $D$ into a $D$, and, in addition $(c)$ joined two words

1 Journal of Theological Studies vol. xviii p. 265.

2 Ibrd. p 266.

4 Ibud. p $27^{2}$

5 I. C. C. Psalms vol. ii p. 233. 
(ל) which were clearly and plainly separated by a final consonant (ם).

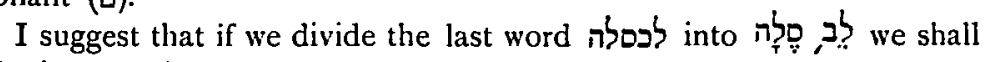
obtain a reading

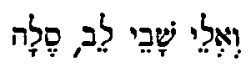

which is as good as the one suggested in I. C C. and also removes the difficulties $(b)$ and $(c)$. Dr Barnes's theory then proves most valuable here also, for a very appropriate Midrash would throw light on this Selah. The verse runs:

$$
\begin{aligned}
& \text { 'He will speak peace } \\
& \text { iص }
\end{aligned}
$$

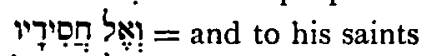

$$
\begin{aligned}
& \text { 然 = and to the that return with [all] their heart, } \\
& \text { i. e. the Penitents. }
\end{aligned}
$$

We have here three degrees: (i) People, (ii) Saints, (iii) Penitents. It is obvious that (ii) is higher than (i). The reader would, therefore, expect (iii) to be higher even than (ii). But how could it be said that the sinner who repented was on a higher spiritual level than the saint who never sinned? SELAH, therefore, is added, sic! So it is. The Talmud ${ }^{1}$ definitely declares in the name of $R$. Abahu :

\section{במקום שבעלי תשובה עומדין

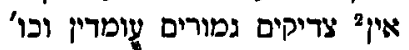

'The spiritual level attained by the Penitents is not accessible to the wholly Righteous, ${ }^{2}$ as it is written, \&c.' This Midrash asserts that the sinner who has.been the victim of temptations, and after having been the prey of evil habits whi'ch have become with him altera natura, abandons his wicked ways and returns to the path of righteousnessis considered superior to the wholly righteous who bas never experienced the temporary pleasures of sin or has perhaps never been tossed on the waves of temptation. The order, therefore, (i) People, (ii) Saints, and (iii) Penitents is quite correct, being an ascending order of spiritual values. Selah warns us not to change this order and calls attention to the quoted Midrash.

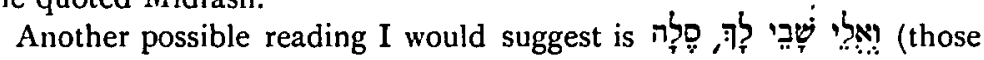
that return to thee, SELAH). This does not affect the Midrash, but involves a change of the person. It has, however, the advantage of 1 avoiding the change of any of the letters of לכסלה.

ISRAEL W. SLOTKI.

1 Talmud Babli, Berahoth, fol. 34 b.

2 The Syriac, it is interestıng to note, translates 